\title{
First evidence of virus-like particles in the bacterial symbionts of Bryozoa
}

\author{
A. E. Vishnyakov ${ }^{1}$, N. P. Karagodina ${ }^{1}$, G. Lim-Fong ${ }^{2}$, P. A. Ivanov ${ }^{3}$, T. F. Schwaha ${ }^{4}$, \\ A. V. Letarov ${ }^{3,5} \&$ A. N. Ostrovsky ${ }^{1,6 \bowtie}$
}

Bacteriophage communities associated with humans and vertebrate animals have been extensively studied, but the data on phages living in invertebrates remain scarce. In fact, they have never been reported for most animal phyla. Our ultrastructural study showed for the first time a variety of viruslike particles (VLPs) and supposed virus-related structures inside symbiotic bacteria in two marine species from the phylum Bryozoa, the cheilostomes Bugula neritina and Paralicornia sinuosa. We also documented the effect of VLPs on bacterial hosts: we explain different bacterial 'ultrastructural types' detected in bryozoan tissues as stages in the gradual destruction of prokaryotic cells caused by viral multiplication during the lytic cycle. We speculate that viruses destroying bacteria regulate symbiont numbers in the bryozoan hosts, a phenomenon known in some insects. We develop two hypotheses explaining exo- and endogenous circulation of the viruses during the life-cycle of $B$. neritina. Finally, we compare unusual 'sea-urchin'-like structures found in the collapsed bacteria in $P$. sinuosa with so-called metamorphosis associated contractile structures (MACs) formed in the cells of the marine bacterium Pseudoalteromonas luteoviolacea which are known to trigger larval metamorphosis in a polychaete worm.

Viruses are found in all kingdoms of living organisms and are best studied in those that have an applied or medical value $\left({ }^{1-4}\right.$, https://talk.ictvonline.org/taxonomy/). In addition to harboring the viruses replicating in eukaryotic cells, all known animals (as well as other multicellular organisms) are associated with specific microbial communities that include viruses infecting their symbiotic microorganisms. Most of these viruses are bacteriophages. Although the bacteriophage communities (viromes) of vertebrates are much better studied (reviewed in refs $^{5-7}$ ), some data are also available for invertebrates. For example, the viral communities associated with the cnidarian $H y d r a^{8,9}$ and certain scleractinian corals ${ }^{10,11}$ have been recently characterized using metagenomic methods. These studies showed that such communities are species-specific and may be significant for homeostasis of the animal hosts.

In addition to the complex microbiomes associated with invertebrate digestive systems or body surfaces, some species harbor specific bacterial symbionts that may be vertically transmitted. Although such symbionts are either intracellular or live in the host tissues (sometimes in special organs), they can also harbor bacteriophages. The best-known example is Wolbachia bacteriophage WO. The symbiotic bacteria Wolbachia exert a major influence on their arthropod hosts by manipulating their reproduction and providing increased resistance to infections ${ }^{12}$. In turn, the bacteriophage WO influences the bacterial titer in the host tissues ${ }^{13}$. This phage also encodes proteins important for bacterium interactions with the host ${ }^{14}$.

In the marine realm, the large variety of viruses are found across diverse taxa, including protists and various invertebrates such as sponges, cnidarians, flatworms, polychaetes, mollusks, crustaceans and echinoderms (reviewed in $^{15-19}$ ); see also ${ }^{20-26}$ and references therein). Being present in large numbers in the seawater ${ }^{27,28}$, viruses, among others, enter suspension-feeders (e.g. $\left.{ }^{29}\right)$. Indeed, by filtering enormous volumes of water, sea

${ }^{1}$ Department of Invertebrate Zoology, Faculty of Biology, Saint Petersburg State University, Universitetskaja nab. 7/9, Saint Petersburg, Russian Federation 199034. '2Department of Biology, Randolph-Macon College, 304 Caroline Street, Ashland, VA 23005, USA. ${ }^{3}$ Research Centre of Biotechnology, Winogradsky Institute of Microbiology, Russian Academy of Sciences, pr. 60-letiya Oktyabrya 7 bld. 2, Moscow, Russian Federation 117312. "Department of Evolutionary Biology, Faculty of Life Sciences, University of Vienna, Althanstrasse 14, 1090 Vienna, Austria. ${ }^{5}$ Department of Virology, Faculty of Biology, Lomonosov Moscow State University, 1-12 Leninskie Gory, Moscow, Russian Federation 119234. ${ }^{6}$ Department of Palaeontology, Faculty of Earth Sciences, Geography and Astronomy, Geozentrum, University of Vienna, Althanstrasse 14, 1090 Vienna, Austria.『email: letarov@gmail.com; a.ostrovsky@spbu.ru 
sponges acquire viruses that infect their cells $s^{30-32}$ as well as their bacterial symbionts ${ }^{33}$. Corals, together with their eukaryotic and prokaryotic symbionts, harbor a variety of viruses too (e.g. ${ }^{34-40}$ ). Similarly, filter-feeders such as bivalve mollusks and tunicates and bacteria living in them also acquire viruses (reviewed in ${ }^{41-44}$ ). Recently a bacteriophage was found to enhance the biofilm formation in the gut of an ascidian by interacting with its bacterial hosts ${ }^{45}$.

The phylum Bryozoa is comprised of active filterers that feed mainly on microscopic algae, gathering them out of seawater ${ }^{4-50}$. Together with sponges and cnidarians this group of colonial invertebrates is among the dominating foulers in many bottom communities from the intertidal zone to a depth of $8 \mathrm{~km}^{51-54}$. Although viruses were never reported from bryozoans before, symbiotic associations with bacteria are known in species from several families of the order Cheilostomata, the largest bryozoan group (e.g. ${ }^{5-61}$, reviewed in ${ }^{62}$ ). The symbionts are reportedly vertically transmitted via the larval stage ( ${ }^{63-69}$ and references therein). During our ongoing research on bryozoan prokaryotic symbionts, we discovered presumed virus-like particles and virus-related structures associated with bacteria in two bryozoan species from two different families and distant localities. This paper presents the first description of the VLP (supposedly bacteriophages) in Bryozoa and their effect onto their bacterial hosts. We also discuss the possible ways of the virus transmission and circulation and their role in these symbiotic systems.

\section{Materials and methods}

Animal material collection, fixation and microscopy. Colonies of the cheilostome bryozoan Bugula neritina (Linnaeus, 1758) (Bugulidae) (Fig. 1A) were collected intertidally on Atlantic Beach, Jaycee Park, Morehead City, North Carolina, USA, in spring 2011. Paralicornia sinuosa (Canu \& Bassler, 1927) (Candidae) (Fig. 1B) was collected by SCUBA-diving in the vicinity of the Lizard Island Research Station, Great Barrier Reef, Coral Sea, Australia, on 4, 5 and 10 October 2012 between 6 and $12 \mathrm{~m}$ depth.

Both species were collected and fixed aiming ultrastructural studies focused on the host-symbiont spatiotemporal interactions. No molecular work was planned in a frame of this project that is why no ethanol-fixations were made. For microscopical research colony fragments were fixed during $3-4 \mathrm{~h}$ after collecting in $2.5 \%$ glutaraldehyde (buffered in $0.1 \mathrm{M} \mathrm{Na}$-cacodylate containing $10 \%$ sucrose (pH 7.4)). They were postfixed with a $1 \%$ solution of osmium tetroxide $\left(\mathrm{OsO}_{4}\right)$. Decalcification was conducted for $24 \mathrm{~h}$ in $2 \%$ aqueous solution of EDTA. After this step the fragments were dehydrated in a graded ethanol series (30-50-70-80-90-100\%) and embedded in epoxy resin type TAAB 812. Postfixation, decalcification and embedding of bryozoan fragments to the resin were made in a less than one month period after fixation.

Embedded specimens were sectioned (70 nm thick) using a Leica EM UC7 microtome (Leica Microsystems, Wetzlar, Germany). To find the area for transmission electron microscopy (TEM), the histological sections $(1.0 \mu \mathrm{m}$ thick) were prepared for light microscopy and stained with Richardson's stain using standard methods ${ }^{70}$. We sectioned seven branches of $B$. neritina and four branches of $P$. sinuosa. Ultrathin sections were picked up with single slot copper grids with formvar support film and contrasted with uranyl acetate and lead citrate. Semithin sections were analyzed using an AxioImager.A1, Zeiss microscope (Zeiss, Oberkochen, Germany). Ultrathin sections were examined with a Jeol JEM-1400 microscope (JEOL Ltd., Japan).

Bacterial and bacteriophage strains and their cultivation. To compare the objects found in the bacterial symbionts of Bugula neritina and reminiscent the VLPs, we prepared a suspension of Escherichia coli cells infected by bacteriophage RB49 (a T4-related virus) and visualized them using the same fixative and following the same procedure as used for bryozoan samples.

E. coli C600 strain and bacteriophage RB49 were from the collection of the Laboratory of Microbial Viruses, Winogradsky Institute of Microbiology. For the infection experiment the overnight culture of E. coli F5 (10.1007/ s00705-019-04371-1) was grown in LB medium at $37^{\circ} \mathrm{C}$ with agitation. The culture was diluted 100-fold with the same medium and cultured under the same conditions up to $\mathrm{OD}_{600} 0.3$. This optical density corresponds to $2 \times 10^{7}$ c.f.u. $\mathrm{ml}^{-1}$. Phage RB49 lysate was added to $3 \mathrm{ml}$ of the bacterial culture up to the multiplicity of infection of 5 . The culture was further incubated $15 \mathrm{~min}$ and then the cells from $1 \mathrm{ml}$ of the infected culture were spun down in the table-top centrifuge at $10000 \mathrm{~g}$ for $40 \mathrm{~s}$. The supernatant was removed and $200 \mu \mathrm{l}$ of the same fixative solution that was used for the animal material was added, and the samples were then processed for thin sectioning and TEM study following the same protocol.

\section{Results}

Colonies of both studied species, Bugula neritina and Paralicornia sinuosa, are lightly calcified, erect and branched (Fig. 1A,B \& inserts). Histological sections and TEM study of colony fragments showed the presence of symbiotic bacteria in the funicular system in both species (Fig. 1C-F). In B. neritina the densely packed bacterial cells were present in so-called 'funicular bodies', which are swollen areas of the transport funicular cords crossing the coelomic cavity of autozooids (Figs. 1C,D, 2 (box 1)), and in P. sinuosa they were present inside the funicular cords themselves (Fig. 1E,F). Also, in B. neritina, bacteria were additionally recorded in and between the epidermal cells of the tentacles (Fig. 2 (box 2)), between and inside the cells of the body wall (epithelium of introvert and peritoneal cells of ooecial vesicle) (Fig. 2 (boxes $3 \& 4$ )) and in the presumed coelomocytes situated on the epithelial lining of the ooecial vesicle (Fig. 2 (box 4)) plugging an entrance to the brood chamber (ovicell). In both bryozoan species we detected intact (non-modified) as well as morphologically altered bacterial cells.

Ultrastructural study of the bacterial symbionts in both bryozoan hosts showed the presence of objects resembling virus-like particles (VLP) and/or virus-related structures. Our interpretation of the discovered particles (see below) as VLPs was based on their size, morphological features and in their occurrence in/near structurally altered bacterial cells. Although the virions of bacteriophages are dimensionally and morphologically stable 


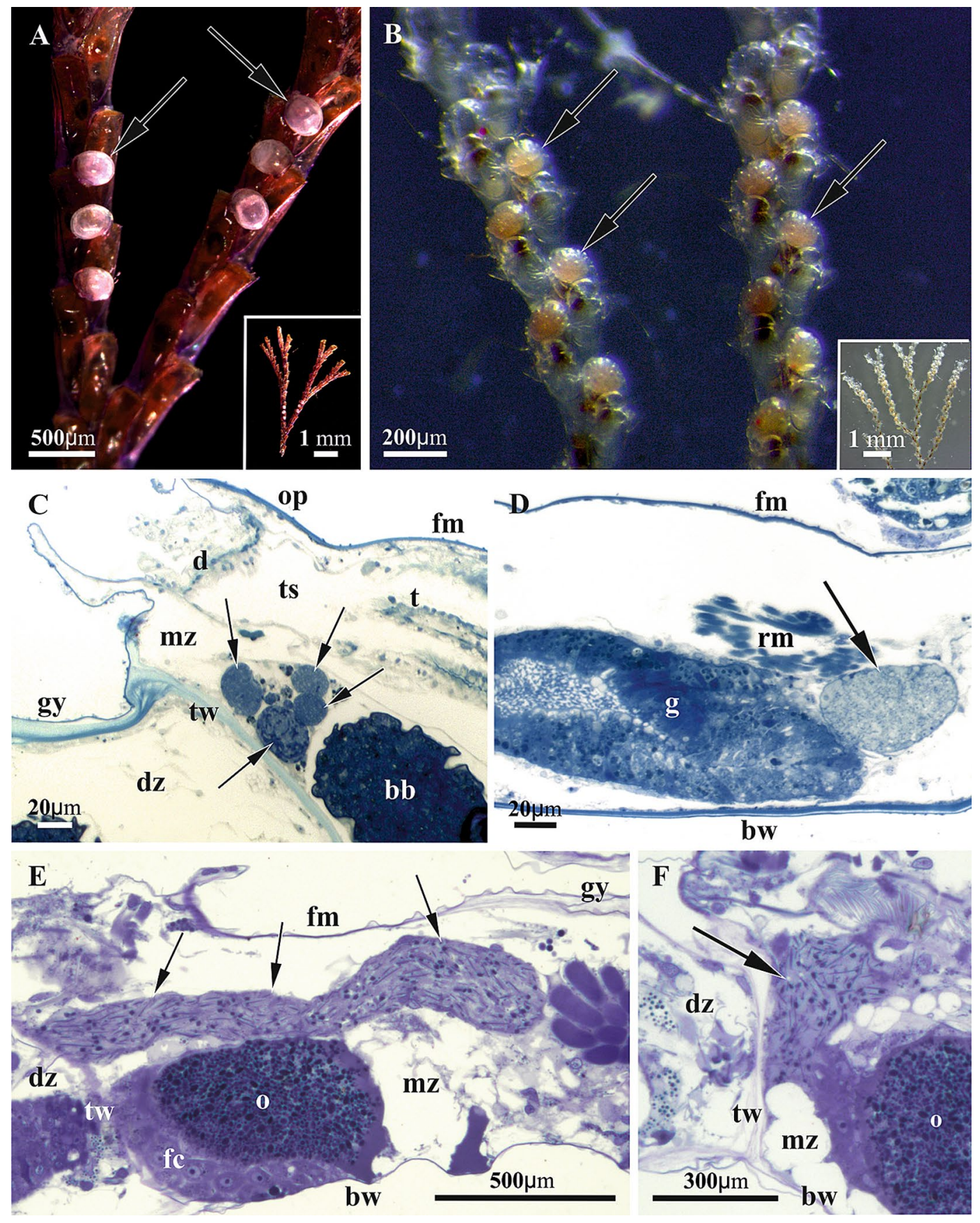

Figure 1. (A,B) General view of colony branches of Bugula neritina (A, insert) and Paralicornia sinuosa (B, insert) (brood chambers (ovicells) with embryos shown by arrows). Stereomicroscope. (C-F), histological sections of autozooids of $B$. neritina (C,D) containing bacteria inside funicular bodies, and of $P$. sinuosa (E,F) with symbionts filling funicular cords (shown by arrows in both cases). Paracrystalline structures are visible as black 'dots' and 'lines' inside funicular cords in (E,F). Light microscopy. Abbreviations: bb, brown body (degenerated polypide); bw, basal wall; d, diaphragm; dz, distal zooid; fc, follicle cells; fm, frontal membrane; g, gut; gy, gymnocyst; mz, maternal zooid; o, oocyte inside ovary; op, operculum; t, tentacles of retracted polypide; ts, tentacle sheath; tw , transverse wall.

and uniform, both fixation and TEM observations potentially could generate a 'false' visual diversity since the capsids are sectioned at different levels and viewed at different angles, and the tails (if present) may be hidden.

Comparison of E. coli cells infected by the phage RB49 showed that the bacteriophage heads and proheads exhibited a significant degree of apparent morphological variation (Fig. 3) similar to VLPs observed in bryozoans (Figs. 4, 5E,F, 6, 7C,D). The tails of RB49 particles could not be reliably seen inside the infected bacterial cells. 


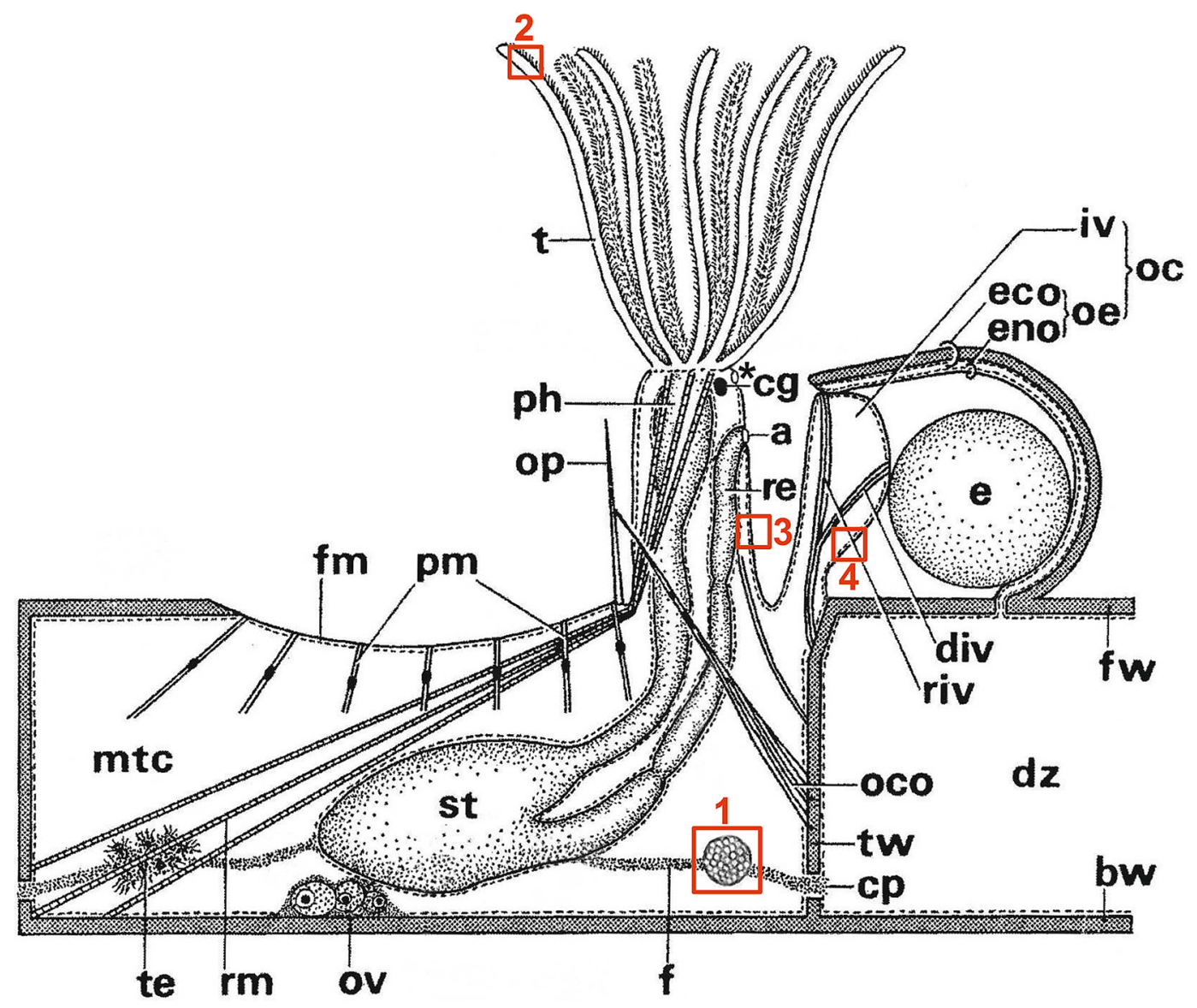

Figure 2. Scheme of cheilostome fertile autozooid with protruded tentacle crown and embryo in the brood chamber (ovicell) formed by distal autozooid (shown in part). Boxes indicate the sites where bacteria were found. Box 1, funicular body (corresponds to Fig. 1C,D); box 2, tentacle epithelium (corresponds to Fig. 5); box 3 , wall of tentacle sheath (introvert) - flexible part of the body wall everting and inverting during the tentacle expansions and retractions; box 4, wall of the inner (ooecial) vesicle-outfold of the body wall plugging the entrance to the ovicell (brood chamber) (corresponds to Fig. 7A,B). Abbreviations: a, anus; bw, basal wall; $\mathrm{cg}$, cerebral ganglion; $\mathrm{cp}$, communication pore; div, depressor muscle of inner (ooecial) vesicle; $\mathrm{dz}$, distal zooid; e, embryo; eco, ectooecium; eno, entooecium; f, funiculus; fm, frontal membrane; fw, frontal wall; iv, inner (ooecial) vesicle; mtc, coelom of maternal zooid; oc, ovicell; oco, occlusor of operculum; oe, ooecium; op, operculum; ov, ovary; ph, pharynx; pm, parietal muscles; re, rectum; riv, retractor muscle of inner (ooecial) vesicle; rm, retractor muscle of polypide; st, stomach; t, tentacles; te, testis; tw, transverse wall. Asterisk indicates supraneural coelomopore (from Ryland 1970, modified).

VLPs in bacterial symbionts of Bugula neritina. In B. neritina the virus-like particles were found in the symbiotic bacteria associated with the tentacle epidermis (Figs. 4, 5) and epithelium of the tentacle sheath (introvert), and those located inside the funicular bodies (Figs. 6, 7C,D, 8). In these three loci, bacteria were morphologically different (those in tentacles vs in introvert and funicular bodies), supposedly belonging to two different species. Else, in the tentacles and funicular bodies bacterial cells fall into three 'ultrastructural types', presumably representing the successive stages of bacterial transformation/destruction during the viral lytic cycle. Solely 'ultrastructural type II' was recorded in the wall of the introvert. The VLPs became visible in the bacteria of 'types' II and III.

VLPs and bacteria in tentacles. The VLPs inside bacteria in the tentacle epidermal (ciliated) cells were predominantly oval and isometric, with diameters varying between 50 and $65 \mathrm{~nm}$. Being either electron-dense or translucent, their content probably reflects different virion assembly intermediates (Fig. 4A,B). Some VLPs with relatively translucent content were detected on the surface of bacterial cells or between them and bryozoan epidermal cells (Fig. 4C, D). They were either oval or polygonal with clearly recognizable thick 'cover'/peripheral layer (Fig. 4D).

Bacteria of 'type I' represent non-altered cells with an ultrastructure typical for Gram-negative bacteria. These were coccoid or slightly elongated cells (Fig. 5A-C) with a diameter/length of about $0.5-0.7 \mu \mathrm{m}$. A welldefined electron translucent nucleoid zone is surrounded by a thin peripheral layer of electron-dense cytoplasm enveloped by two membranes. Some of the cells were obviously dividing. Bacteria were recorded either directly 

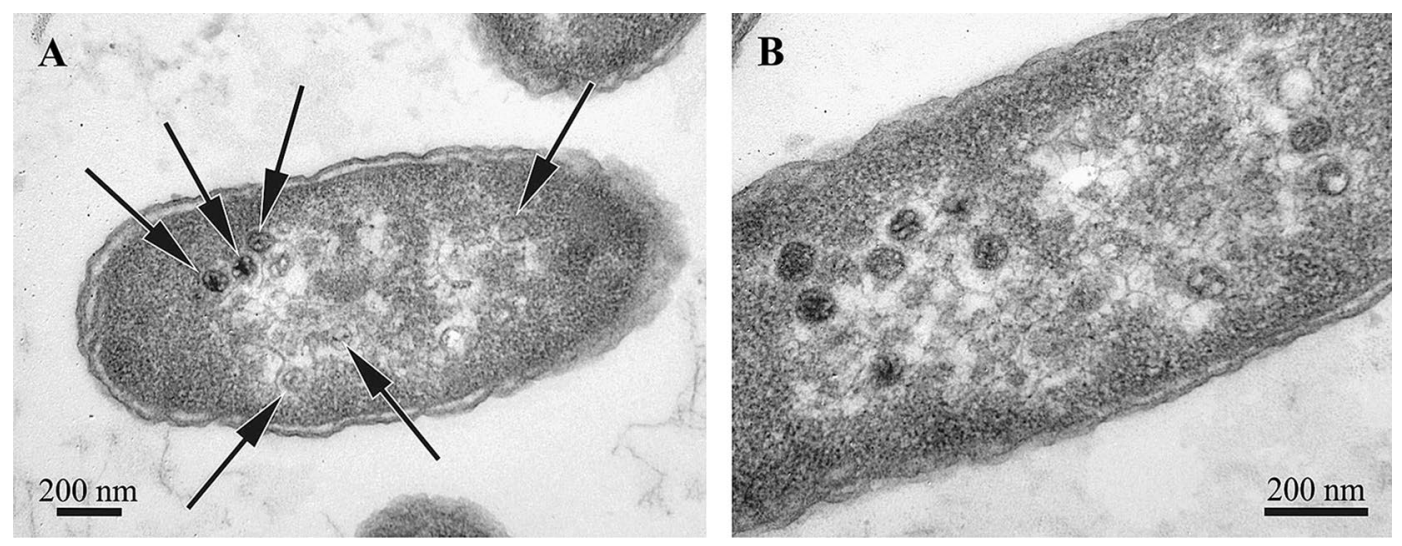

Figure 3. Thin sections of E. coli F5 cells infected by the bacteriophage RB49 (15 min post infection). Bacteriophage heads and proheads (both empty and partially filled) are visible (arrows on A). Note that the capsids do not appear exactly uniform and the tails are not visible.
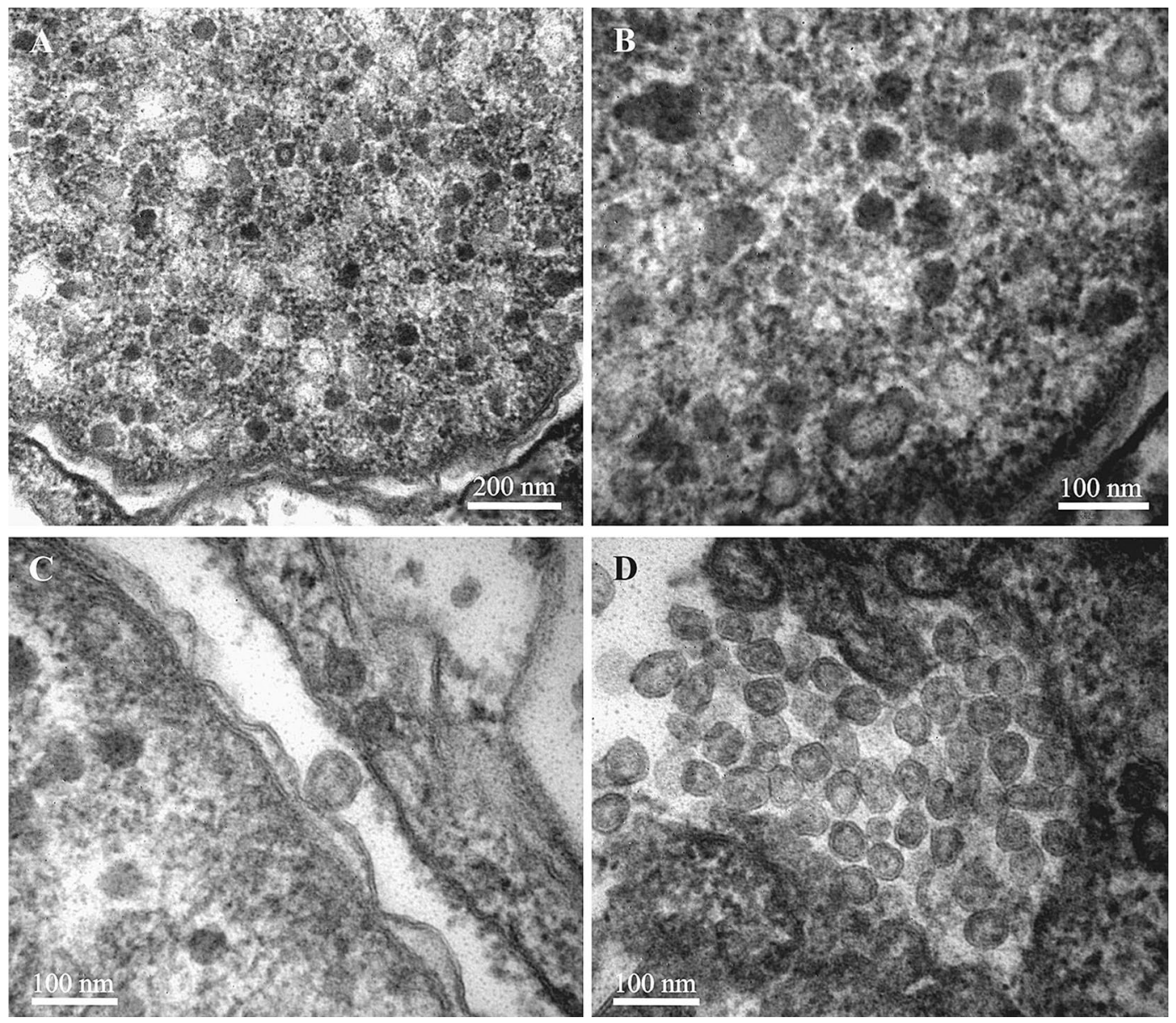

Figure 4. Virus-like particles associated with symbiotic bacteria in the tentacles of Bugula neritina. (A,B) Electron-dense and electron-translucent VLPs inside the cytoplasm of the bacterial cell of 'type III'. (C) VLP inside (left) and on the surface of the bacterial host. (D) virions outside bacteria between epithelial cells of a bryozoan. TEM.

in the cytoplasm or inside large vacuoles of the tentacle epidermal cells, individually or in groups. Some of them presumably occupied intercellular spaces. VLPs were not seen inside or between the 'type I' bacterial cells.

'Type II' bacterial cells (presumably next stage of their transformation) were rod-like and much larger than the coccoid form, reaching lengths of $4-5 \mu \mathrm{m}$ and diameters of about $1.5 \mu \mathrm{m}$ (Fig. 5C-E). The cytoplasm was granular 

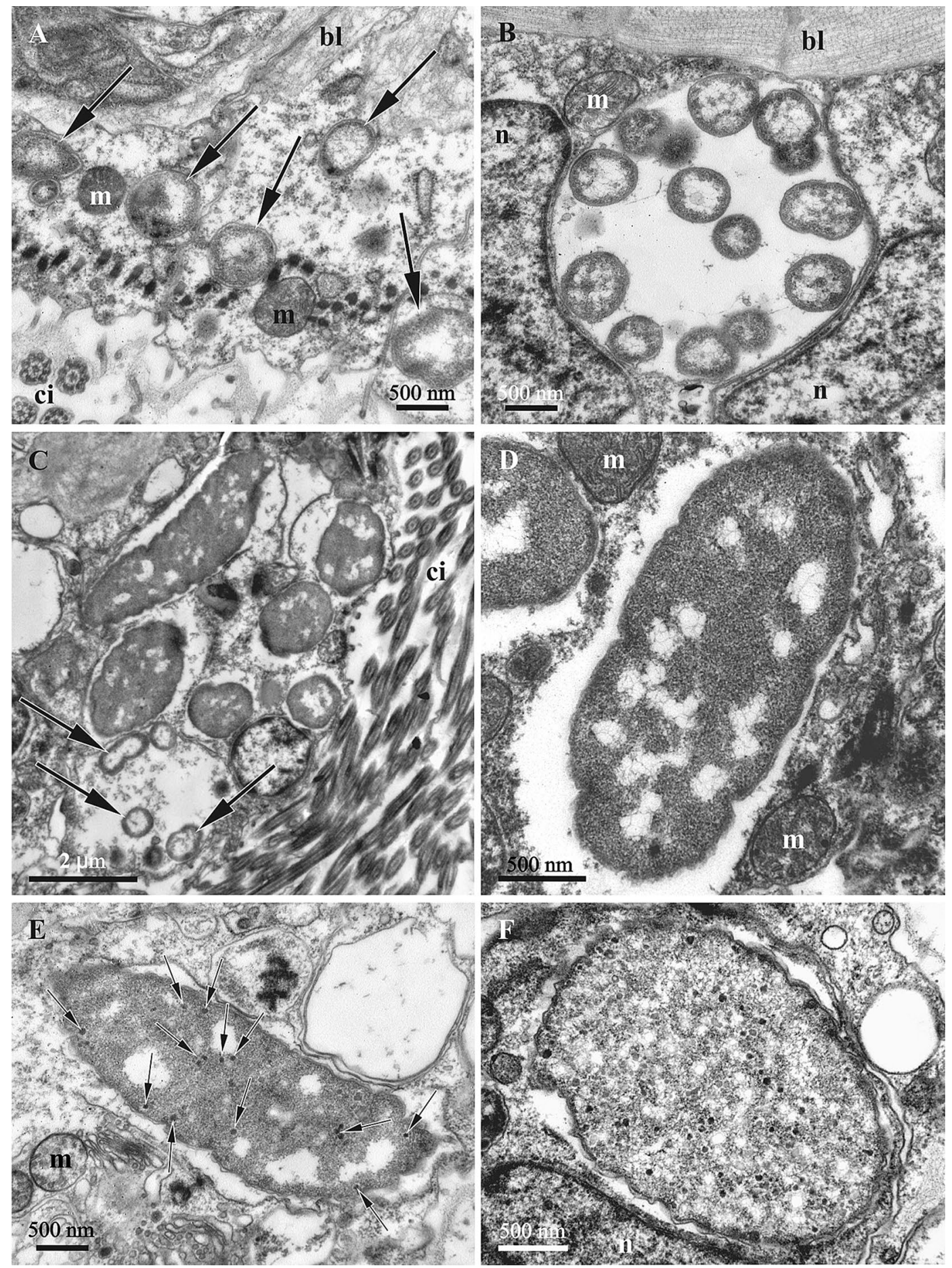

Figure 5. Symbiotic bacteria inside tentacles of Bugula neritina. TEM. (A,B) coccoid symbiotic bacteria of 'type I' inside the cytoplasm (A, arrows) and a large vacuole (B) in the ciliated cells of the tentacles (sectioned kinetosomes and cilia are visible in the lower half of the image (A). (C) groups of smaller coccoid bacteria of 'type I' (arrows) and the larger rod-like bacteria of 'type II'. (D,E), 'type II' bacterial cells without (D) and with (E) few electron-dense virus-like particles (little arrows). (F) symbiotic bacteria of 'type III' inside with viral particles in their cytoplasm. TEM. Abbreviations: bl, basal lamina; ci, cilia; m, mitochondria; n, nucleus.

and electron-dense most of the volume, with the translucent nucleoid zone strongly reduced and fragmented. The cell wall was wavy. Some of these bacteria showed the presence of scant VLPs (Fig. 5E). The membranes of the vacuoles containing the 'type II' bacteria were often not clearly recognizable, possibly destroyed (Fig. 5). 

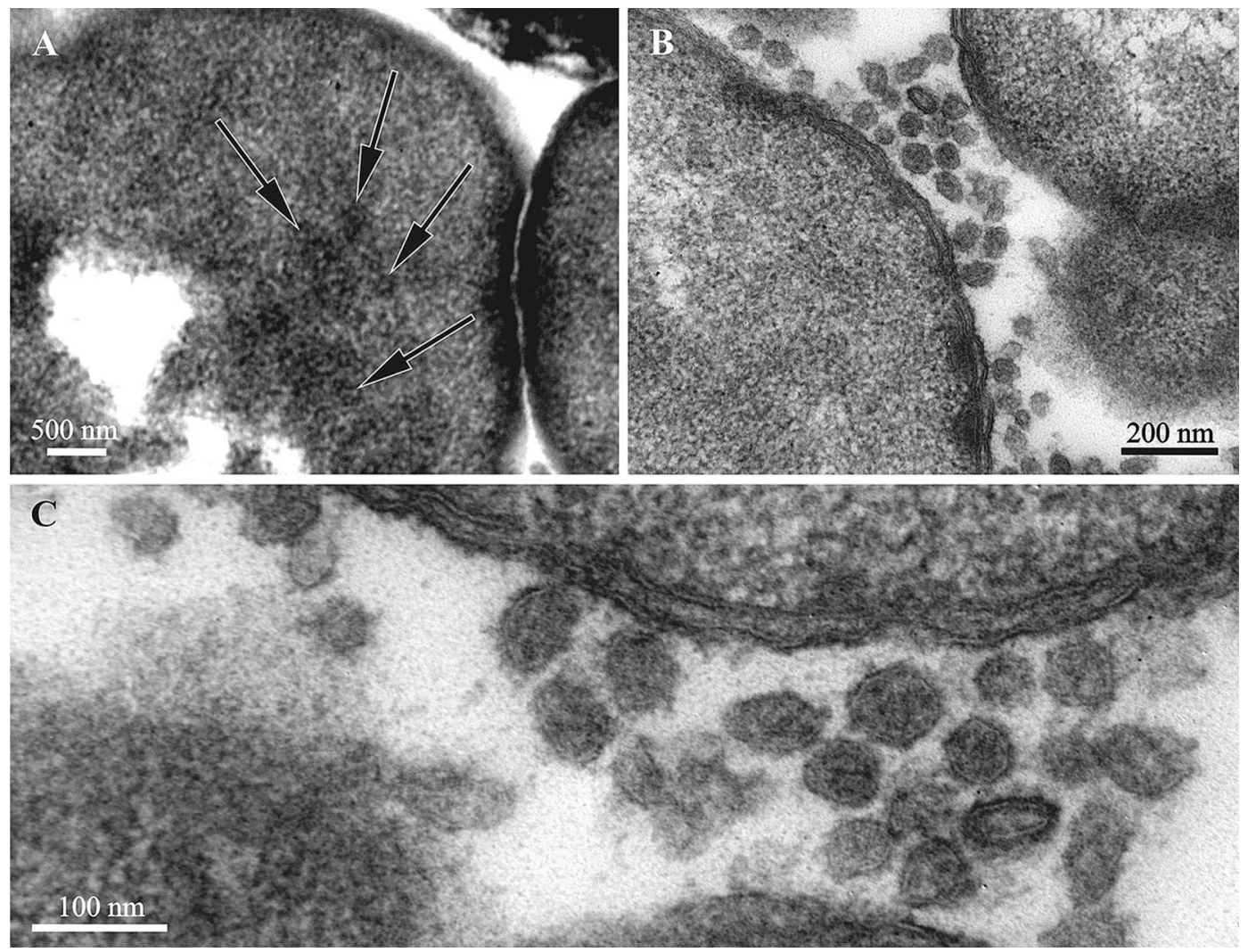

Figure 6. Virus-like particles inside (arrows) (A) and outside (B,C) of symbiotic bacteria in the funicular bodies of Bugula neritina. A, bacteria of 'type II'. (B,C) VLP between 'type III' bacteria. TEM.

'Type III' bacteria were rod-like or ovoid. Their length was the same as in 'type II' cells, but the diameter increased up to 2-2.5 microns. There were no traces of the nucleoid zone in 'type III' cells, and the cytoplasm was filled with abundant VLPs (Fig. 5F).

The 'type III' bacterial cells were usually detected closer to the apical parts of the tentacles, and their numbers were significantly lower than the number of intact coccoid bacteria ('type I') distributed through the entire tentacle length.

VLPs and bacteria inside autozooid. The VLPs associated with the bacteria found in the epithelium of the introvert and filling the funicular bodies (swollen parts of the funicular system, Figs. 1C,D, 2) of B. neritina were oval-polygonal, isometric, with a capsid diameter of 50-70 $\mathrm{nm}$ and thick peripheral layer (Fig. 6C). Most virions were detected in the spaces between bacterial cells (in both introvert and funicular bodies) (Figs. 6B,C, 7C,D), but individual VLP were also visible in the cytoplasm of bacteria (in the funicular bodies) (Fig. 6A).

As was the case in the tentacles, the three bacterial 'ultrastructural types' (but of presumably different species, see above) were also detected inside autozooids. Intact Gram-negative bacterial symbionts ('type I') were found in the presumed coelomocytes and in the peritoneal cells of the ooecial vesicle wall (Fig. 7A,B). They were rodlike (length 2.0-2.5 $\mu \mathrm{m}$ and diameter $0.4 \mu \mathrm{m}$ ), had two outer membranes, a well-defined nucleoid zone and a thin layer of cytoplasm. They were present in groups in the cytoplasm as well as in the vacuoles. No VLPs were recognizable in them.

The 'type II' bacterial cells found in the epithelium of the introvert, and in the funicular bodies had a wide oval, often irregular shape (length up to $4.0-4.5 \mu \mathrm{m}$, width up to 1.5-1.7 $\mu \mathrm{m}$ ) (Figs. 6A, 7C, 8A,B). Their cytoplasm was electron-dense and their nucleoid was fragmented (Fig. 7C). In some of these bacterial cells, 'tube'-like structures 40-50 nm thick were detected in the cytoplasm, being separated or assembled into groups (Fig. 8A,B). The walls of these 'tubes' were morphologically and dimensionally similar to the membranes of the bacterial cell wall. In some cases these 'tubes' and cell membranes were connected.

The shape and size of the 'type III' bacterial cells found in the funicular bodies (Figs. 7D, 8C-F) were about the same as in 'type II'. The cytoplasm was relatively translucent and mostly homogeneously flocculent. Some of the 'type III' bacteria showed two well-recognizable, albeit deformed, cell membranes (Figs. 6B,C, 7D). Some of them, similar to the 'type II' bacteria (Fig. 8A,B), contained 'tube'-like structures. In addition, only one cell membrane was often recognizable in the 'type III' bacteria that presumably were on the late stage of degradation (Fig. 8C-F). They contained large, twisted or curled electron-dense bodies with a spiral arrangement of parallel membranes. The bodies were up to several micrometers long, while their thicknesses varied, sometimes reaching $135 \mathrm{~nm}$. The shape of these bodies strongly varied-we detected rings, U-shaped figures, complex multiple 

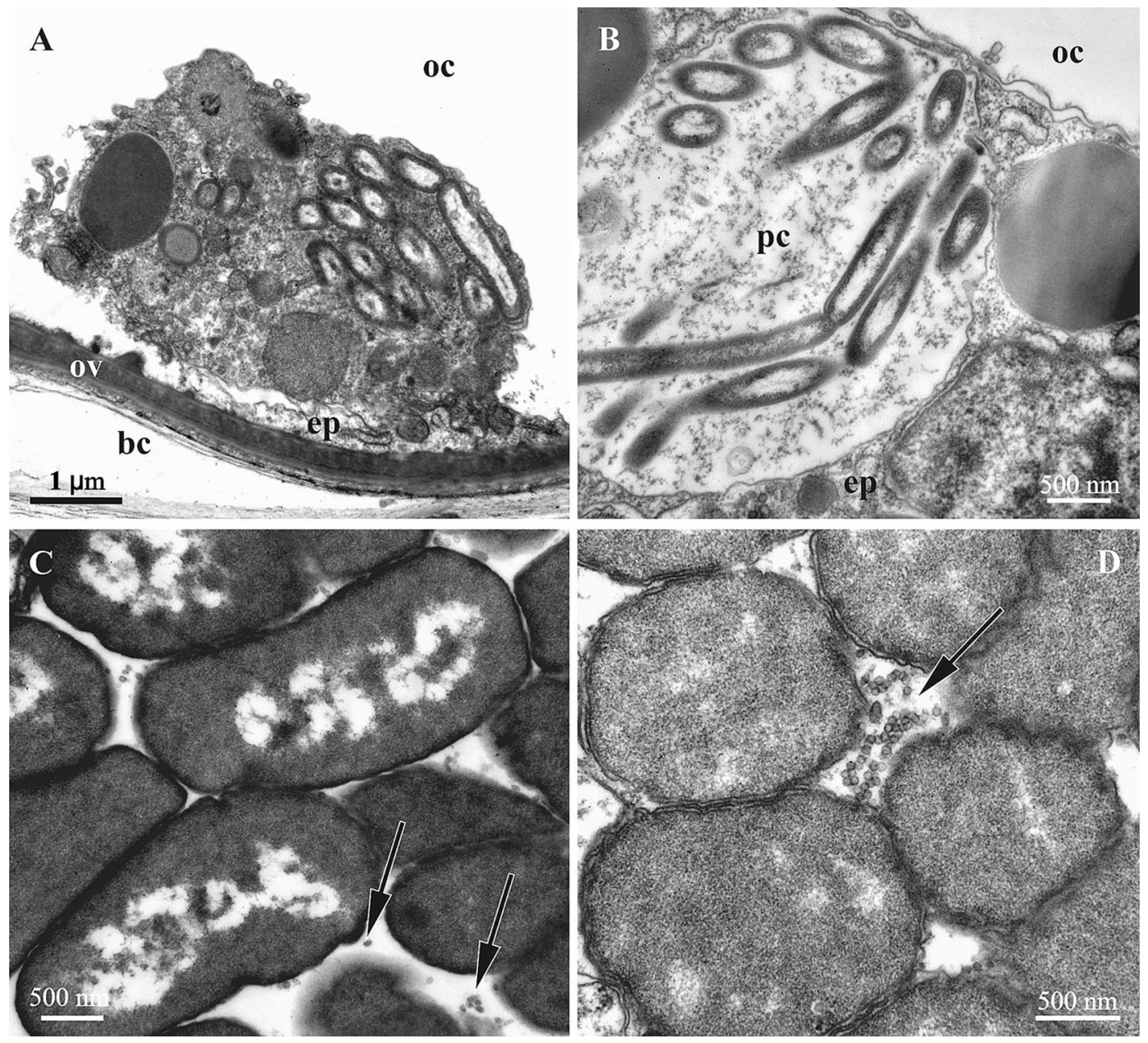

Figure 7. Symbiotic bacteria inside autozooids of Bugula neritina. A, B, intact bacteria of 'type I' in the cytoplasm of presumed coelomocyte (A) and peritoneal cell (B) of the body wall (ooecial vesicle). (C,D) bacteria in the funicular bodies: 'type II' (C) and 'type III' (D) with VLP visible in between bacterial cells (arrows). TEM. Abbreviations: bc, incubation space of brood chamber; ep, epithelial cell; oc, coelom of ooecial vesicle; ov, wall of ooecial vesicle; pc, peritoneal cell.

loops and other configurations. When the bacterial cells were destroyed, these bodies were released in the space between the bacteria.

Funicular bodies contained bacteria of either 'type II' or 'type III' separately, but the funicular bodies with different bacterial 'types' were detected in the same zooids.

Virus-related structures in bacterial symbionts of Paralicornia sinuosa. In $P$. sinuosa the cytoplasm of morphologically altered bacterial cells found in the funicular cords (Fig. 1E,F) contained spherical particles consisting of the cylindrical/tube-like elements evenly radiating from the central double-walled 'core' (Fig. 9). The diameter of these 'sea urchin'-shaped structures was about $300 \mathrm{~nm}$, while the individual cylinders/ tubes were about $120 \mathrm{~nm}$ long and about $20 \mathrm{~nm}$ thick. In cross-section the core with the bi-layered darker periphery (core wall?) and lighter central part were recognizable at high magnification (Fig. 9B). The cylinders/ tubes were apparently interconnected by the electron-dense layer slightly below their distal tips. The proximal ends of the tubes also appear connected, forming the above-mentioned 'double-walled' core of the particle that has a diameter of 50-60 $\mathrm{nm}$. In the medial sections of the particles about 20-21 cylinders/tubes are visible (Fig. 9B and insert), leading to an estimated 400-450 of them in one particle. The particle diameter seems to be stable/identical, suggesting that the size and/or the number of the cylinders/tube-like elements is tightly controlled during particle development.

Similar to Bugula neritina, closer examination of the morphology of bacterial cells also revealed three different 'ultrastructural types', which we again interpret as corresponding to the stages of the virus-like particle development before bacterial lysis. 'Type I'-presumably intact or slightly altered Gram-negative bacteria. Such cells were rod-like, 3-4 $\mu \mathrm{m}$ long and about $1 \mu \mathrm{m}$ wide (Fig. 9C, insert) The central part of the cell is occupied by filaments of nucleoid surrounded by an electron-translucent zone that often included electron-dense areas of various size and shape. The peripheral cytoplasm is electron-dense, granular, without inclusions, surrounded by a plasma membrane that was poorly recognizable in some cases. 

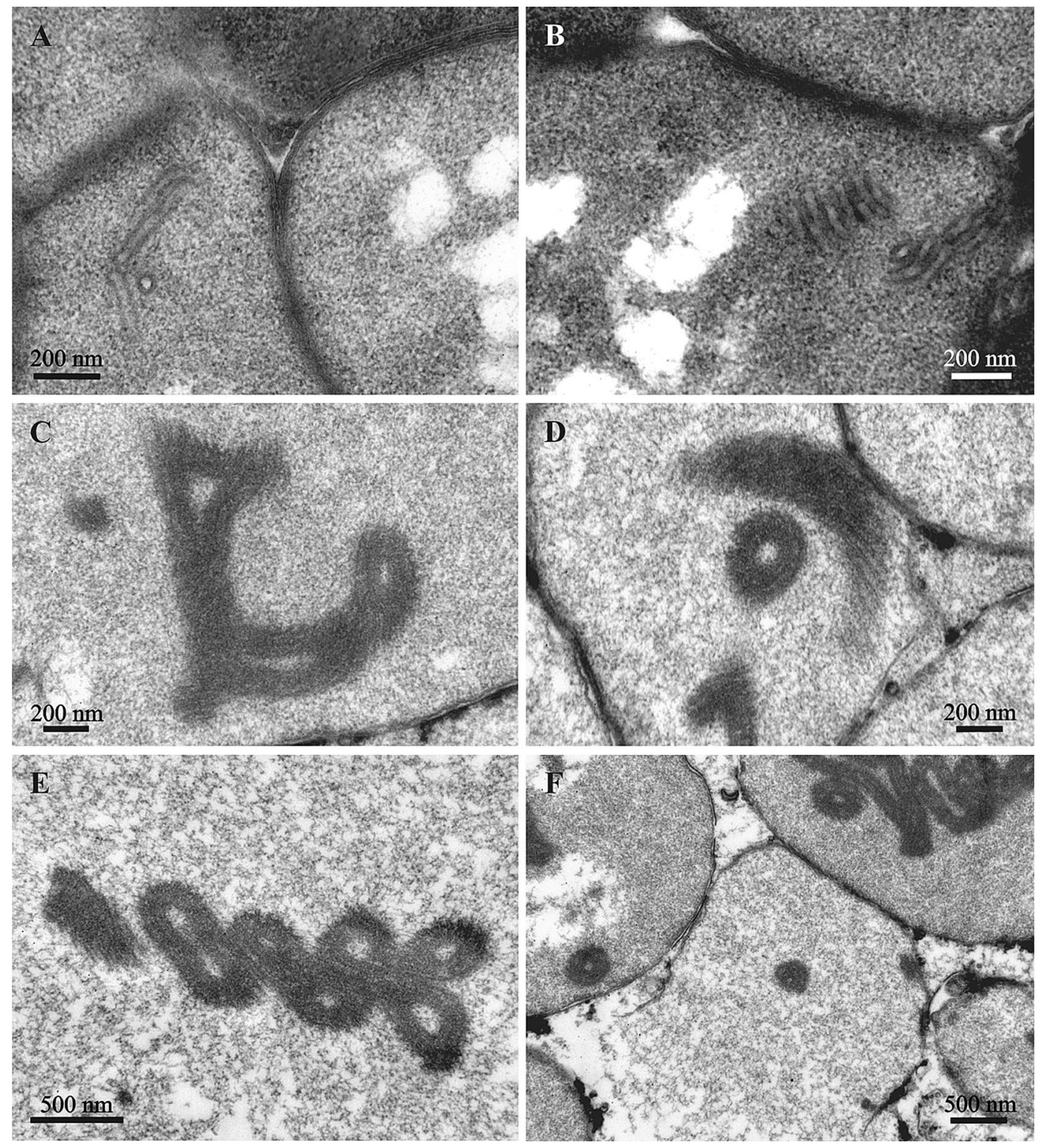

Figure 8. 'Tube'-like structures in the bacterial cells found in the funicular bodies of Bugula neritina. (A,B), bacteria of 'type II' with tube'-like structures in the beginning of their formation. (C-F), fully-formed 'tube'-like structures in the bacteria of 'type III' and in destroyed bacteria (in F).

Bacterial cells of 'type II' presented moderate alterations in the cell ultrastructure presumably corresponding to the initial phase of VLP development. Cell length and width were increased, sometimes doubled (up to 8 and $2 \mu \mathrm{m}$, respectively), and the cell wall often took on a wavy appearance. The nucleoid fibrils disappeared, and most of the cytoplasm became homogeneously electron-dense. The viral particles and paracrystalline structures became visible inside the bacteria (Fig. 9D). In 'type III' cells the VLPs filled most of the cell volume (Fig. 9E). The paracrystalline bodies became more numerous, acquiring very different shapes, from irregular polygons to long rods with a length of up to $8-10 \mu \mathrm{m}$ (Figs. 1E,F, 9E,F). At high magnification the densely packed parallel fibrils were visible in them (Fig. 9F, insert).

After destruction of bacteria, both the viral particles and paracrystals were freely distributed inside the cavity of the funicular cords. In some occasions we observed them in the zooidal coelom too, obviously following disintegration of the funicular cord wall.

\section{Discussion}

Detection of new viruses is often a serendipitous event during ultrastructural studies (e.g. $\left.{ }^{20,23,30}\right)$. In our case we found VLPs when studied of symbiotic associations of bacteria with an invertebrate. We explain the different bacterial 'ultrastructural types' detected in the tissues of two bryozoan species as stages in the gradual destruction of bacterial cells caused by the virus development. 

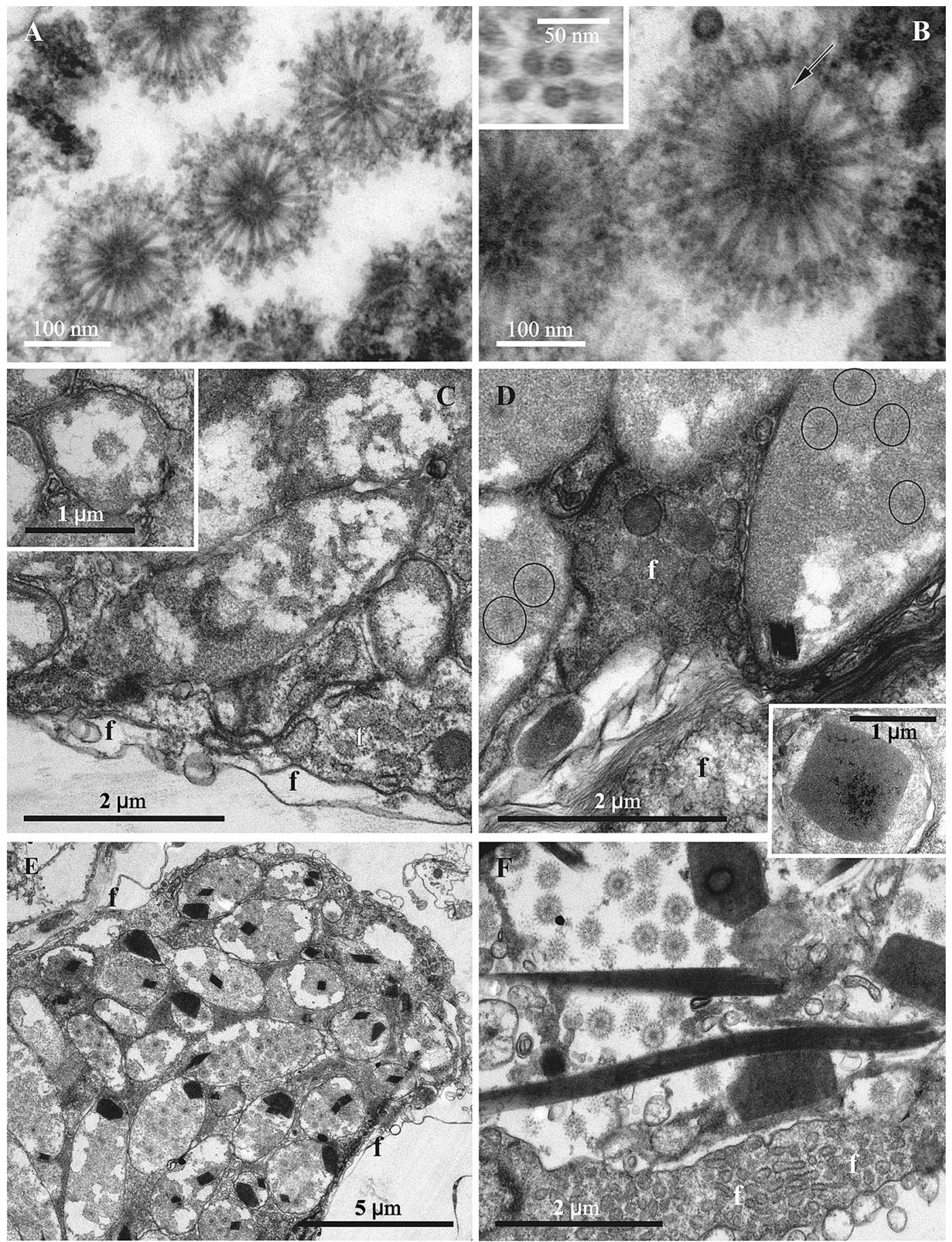

Figure 9. (A,B) Structures presumably derived from viruses in bacterial symbionts of Paralicornia sinuosa. Insert: cross-section of radial cylinders showing darker periphery and lighter central part (also shown by arrow in B) with a dark central 'spot'. (C-F, insert), various stages in the lytic cycle of bacteriophages in the symbiotic bacteria of $P$. sinuosa. (C) and insert, longitudinal and cross-sections of non-/less altered bacteria ('type I' cells) inside funicular cord. (D) VLP (in circles) becoming visible inside bacteria predominantly filled with electrondense cytoplasm ('type II' cells), nucleoid is fragmented and poorly recognizable; insert shows paracrystalline body at higher magnification. (E) bacteria ('type III' cells) filled with viruses and paracrystalline structures. (F) bacteriophages and paracrystals inside the cavity of the funicular cord after bacterial destruction. TEM. Abbreviations: $\mathrm{f}$, cells of funicular cord. 
The two variants of VLPs found in the symbiotic bacteria of Bugula neritina (compare Figs. 4 and 6) were similar to the capsids of tailed bacteriophages. No tails were observed, however. We suggest that the tail appendages are probably present but indiscernible in the TEM-images, as, for example, in the case of podoviruses with their short tails. Nonetheless, we cannot exclude that the VLPs belong to non-tailed phages that possess the virions of similar size such as, e.g. in the family Tectiviridae ${ }^{71}$.

Our observations indicate that the phages of symbiotic bacteria of B. neritina act as pathogenic agents, destroying bacteria in the course of their multiplication in the lytic cycle.

The situation observed in bacteria from the funicular system of $B$. neritina is special. We suggest that the 'tubes' visible in the cells of the second 'morphotype' are invaginations of membranes of the bacterial cell wall, and can later cluster as the bacteria are lysed, forming complex structures in the cytoplasm. Subsequently, elongation and spiral twisting of these 'tubes' could result in the formation of flexible 'rods'. Further curling of these rods yields structures of various shapes. A similar effect is observed in the action of lactocins and of the viruses on Gram-positive bacteria of the genus Lactobacillus ${ }^{72,73}$.

Bacteria discovered in the tentacles and in the introvert wall and the funicular system of $B$. neritina have a different morphology (coccoid vs rod-like), suggesting different (and independent) ways of their acquisition. The former potentially could penetrate into tentacle tissues directly from the surrounding water. This kind of interaction between bryozoan hosts, bacteria and phages might be common, but more extensive ultrastructural research on bryozoan tentacles is required to show whether this mechanism of infection is widespread. A supporting argument in this case is the discovery of similar symbionts and phage particles in the tentacles of B. neritina collected in the Mediterranean Sea on the coast of Spain (Vishnyakov, Schwaha, Souto, Ostrovsky, unpublished data).

The symbiotic bacteria occupying funicular bodies in the B. neritina zooidal cavity have been identified as Candidatus Endobugula sertula responsible for production of bryostatins-cyclic polyketides presumably participating in the regulation of bryozoan oogenesis and protection of free larvae against predation, and also having antitumor activity being considered as potential anti-cancer drug ${ }^{61,68,69}$. These bacteria are vertically transmitted through the larva and are thus inherited by the first zooid (ancestrula) during metamorphosis ${ }^{68,74}$. Zooidal budding then results in colony formation and the spread of the symbionts through it. Occupying the transport funicular system and utilizing the nutrients from it, the symbionts multiply, triggering the formation of the funicular bodies that was recently shown in another cheilostome bryozoan ${ }^{62}$. Bacteria partly stay in these bodies and partly move to the ooecial vesicle of the brood chamber by an unknown mechanism. Woollacott and Zimmer ${ }^{58}$ showed the presence of bacteria inside the lacunae of the funicular cords of $B$. neritina, which could be the pathway for the symbionts traveling through zooids. Our data indicate an opportunity for bacterial transport to the ooecial vesicle by coelomocytes, but more research is needed to evaluate this hypothesis. The bacterial transmission to the wall of the tentacle sheath is enigmatic. These bacteria are very similar/identical to those found in the funicular bodies and posess the VLPs of the same morphology. Their position between/ inside epithelial cells, however, is similar to bacteria found in the tentacles.

The available data are insufficient to conclude whether the VLP production in symbiotic bacteria results from infection by externally acquired bacteriophage particles or is due to induction of the prophages or prophage-like elements present in the genomes of these bacteria. The infection hypothesis seems more plausible for bacteria found in B. neritina tentacles, but the scenario potentially could be different in case of the funicular body symbionts. We suggest that in this species the phages circulate in the bryozoan host population together with bacteria by vertical transfer, which does not require repeated external infection. Those symbionts that remain in the funicular bodies finally collapse due to viral activity. In contrast, some bacteria move by an unknown mechanism from the funicular bodies towards the brood chamber containing phages in the form of prophages in the bacterial genome. We speculate that the superficially intact 'type I' bacteria we found in the peritoneal cells and presumed coelomocytes in the ooecial vesicle are, in fact, lysogenic and may undergo prophage induction. Similar aggregations of the "tiny dark granules" (possibly bacteria) were earlier described and/or illustrated inside or close to the ooecial vesicle in B. neritina $\left({ }^{61}\right.$, p. 8$)$ and a related bryozoan species ${ }^{75-77}$ using histological sections. The reconstructed draft genome of $\mathrm{Ca}$. E. sertula, consisting of 112 contigs, from a metagenomic assembly did not uncover any prophage-like elements ${ }^{78}$; however, it is possible that such elements were absent in those particular specimens (one pooled collection of B. neritina larvae and several autozooids and ovicells of one B. neritina colony), or that these prophages were not recovered by the assembly algorithms. Interestingly, many short contigs $(\sim 2 \mathrm{kbp})$ were recovered from the metagenome ${ }^{79}$, and some of these contigs might represent viral sequences.

The next step is a transfer of infected bacteria from the ooecial vesicle through its wall to the brood cavity. Moosbrugger with co-authors ${ }^{60}$ showed the presence of bacteria inside an ovicell containing an embryo in another bugulid species (see also ${ }^{68}$ ). Accordingly, if our model is correct, prophages are transferred to the brood chamber with their bacterial hosts finally reaching the larvae. This enables them to be transmitted to the next bryozoan generation. Potentially, the phages and bacteria found in the tentacles might circulate in the host in a similar way, but it then remains unclear how they could reach larvae in the brood chamber. The only imaginable strategy is their transfer during oviposition when the tentacle crown delivers the zygote to the brood cavity (its mechanism reviewed in ${ }^{76,80}$ ). This way, however, appears less probable.

The induction hypothesis appears to be the only possibility to explain the formation of the structures observed in Paralicornia sinuosa. These structures do not resemble any known bacteriophages and appear to be too large to be interpreted as the virions of a novel bacteriophage family. At the same time the formation of these structures is clearly associated with cell destruction by lysis. We should add here that after submission of this paper very similar structures were encountered in another cheilostome bryozoan Paracribricellina cribraria (from the distant family Catenicellidae) collected near New Zealand in 2009.

We speculate that the particles observed in P. sinuosa symbionts are similar to the metamorphosis associated contractile structures (MACs) recently discovered in the free-living bacteria Pseudoalteromonas luteoviolacea ${ }^{81}$. 
MACs are encoded by prophage-like elements in the P. luteoviolacea genome, and their formation is associated with host cell death and lysis. Structurally, MAC is an assemblage of multiple contractile systems related to the contractile tails of myoviruses (tailed bacteriophages with contractile tails) (reviewed by ${ }^{82,83}$ ). The tail-like structures in MAC are assembled in a sea urchin-like pattern that fills almost the entire host cell. The baseplates of the individual contractile systems point outwards and are interconnected by a network formed by the homologs of the tail fibers ${ }^{81}$. Interestingly, the formation of MAC in P. luteoviolacea was associated with the formation of 2D paracrystalline arrays that were tentatively interpreted as the crystals of the sheath protein ${ }^{81}$. In $P$. sinuosa bacterial cells, the sea-urchin like structures are also associated with large protein crystals (Fig. 9), adding to the similarity of these two systems. Although the formation of similar crystalline bodies was previously reported in certain cells infected by viruses ${ }^{84}$, the physiology of this process and the possible function of these structures are poorly understood.

The MACs of $P$. luteoviolacea function to deliver a protein signal into the cells of the larvae of the tubeworm Hydroides elegans. The delivery takes place when the larva contacts the biofilm containing the MACs. This causes the contraction of the tail-like structures and the penetration of the tail tube tips into the animal cells ${ }^{85}$. The delivery of the protein signal induces larval metamorphosis ${ }^{81,85}$. It is currently unclear whether bacteria can benefit from this effect.

The features of the structures that we detected in P. sinuosa symbionts are compatible with a presumed MAC-like nature. The length of their cylindrical elements is about $120 \mathrm{~nm}$, i.e. comparable to the phage tail of the bacteriophage $\mathrm{T} 4$ contractile tail $(114 \mathrm{~nm} \text { long })^{86}$. Although no data are currently available on a potential involvement of MAC-related structures in interspecies communications between bacterial symbionts and their $P$. sinuosa host, it seems a plausible hypothesis. In this regard it is important that small (compared to P. luteoviolaceae MAC) particles released by the lysed symbiont cells inside bryozoan host may move from its funicular system to the zooidal coelomic cavity and further to the surrounding water via coelomopores ${ }^{80}$.

Interestingly, the onset of the MACs or VLPs production appears to occur almost simultaneously in multiple bacterial cells within one funicular body (Figs. 7C,D, 9). This suggests the triggering of induction by some cue generated by bacteria or by the animal host.

We speculate that maintaining an excess of symbiotic bacteria in the funicular bodies becomes energetically disadvantageous at a certain point, and viruses destroying bacteria thus act as regulators of their numbers. Such phages are termed mutualistic, and their participation in indirectly regulating the number of symbiotic bacteria and processes carried out by symbionts has been described for aphids and some other insects ${ }^{13,87,88}$. This relationship as also been assumed for the symbiotic associations of cnidarians with their microbial symbionts ${ }^{89,90}$.

Our study is the first step towards future research on viruses of the bacterial symbionts of Bryozoa. The next step should include determination of the systematic status of both the viruses and their bacterial hosts. The wide range of bioactive substances identified from bryozoans (reviewed $\mathrm{in}^{91}$, see also ${ }^{92}$ ) suggests a wide distribution of symbionts inside these invertebrates. These symbionts, in turn, could host various viruses-but this research has just begun.

Received: 14 July 2020; Accepted: 12 November 2020

Published online: 08 January 2021

\section{References}

1. Ohmann, B. \& Babiuk, L. A. Viral infections in domestic animals as models for studies of viral immunology and pathogenesis. J. Gen. Virol. 66, 1-25 (1986).

2. Woolhouse, M., Scott, F., Hudson, Z., Howey, R. \& Chase-Topping, M. Human viruses: discovery and emergence. Phil. Trans. R. Soc. B. 367, 2864-2871 (2012).

3. Johnson, C. K. et al. Spillover and pandemic properties of zoonotic viruses with high host plasticity. Sci. Rep. 5, 14830 (2015).

4. Glennon, E. E. et al. Domesticated animals as hosts of henipaviruses and filoviruses: a systematic review. Veterinary J. 233, 25-34 (2018).

5. Letarov, A. \& Kulikov, E. The bacteriophages in human- and animal body-associated microbial communities. J. Appl. Microbiol. 107, 1-13 (2009)

6. Shkoporov, A. N. \& Hill, C. Bacteriophages of the human gut: the "known unknown" of the microbiome. Cell Host Microbe 25, 95-209 (2019).

7. Kwok, K. T. T., Nieuwenhuijse, D. F., Phan, M. V. T. \& Koopmans, M. P. G. Virus metagenomics in farm animals: a systematic review. Viruses 12, E107 (2020).

8. Grasis, J. A. et al. Species-specific viromes in the ancestral holobiont Hydra. PLoS ONE 9, e109952 (2014).

9. Bosch, T. C., Grasis, J. A. \& Lachnit, T. Microbial ecology in Hydra: Why viruses matter. J. Microbiol. 53, 193-200 (2015).

10. Weynberg, K. D. et al. Coral-associated viral communities show high levels of diversity and host auxiliary functions. PeerJ 5, e4054 (2017).

11. Mahmoud, H. \& Jose, L. Phage and nucleocytoplasmic large viral sequences dominate coral viromes from the Arabian Gulf. Front. Microbiol. 8, 2063 (2017).

12. López-Madrigal, S. \& Duarte, E. H. Titer regulation in arthropod-Wolbachia symbioses. FEMS Microbiol. Lett. 366, fnz232 (2019).

13. Bordenstein, S. R., Marshall, M. L., Fry, A. J., Kim, U. \& Wernegreen, J. J. The tripartite associations between bacteriophage, Wolbachia, and arthropods. PLoS Pathog. 2, e43 (2006).

14. Perlmutter, J. I. et al. The phage gene wmk is a candidate for male killing by a bacterial endosymbiont. PLoS Pathog. 15, e1007936 (2019).

15. Johnson, P. T. Viral diseases of marine invertebrates. Helgolander Meeresunters 37, 65-98 (1984).

16. Weinbauer, M. G. Ecology of prokaryotic viruses. FEMS Microbiol. Rev. 28, 127-181 (2004).

17. Munn, C. B. Viruses as pathogens of marine organisms-from bacteria to whales. J. Mar. Biol. Ass. 86, 453-467 (2006).

18. Lang, A. S., Rise, M. L., Culley, A. I. \& Steward, G. F. RNA viruses in the sea. FEMS Microbiol. Rev. 33, 295-323 (2009).

19. Rosario, K., Schenck, R. O., Harbeitner, R. C., Lawler, S. N. \& Breitbart, M. Novel circular single-stranded DNA viruses identified in marine invertebrates reveal high sequence diversity and consistent predicted intrinsic disorder patterns within putative structural proteins. Front. Microbiol. 6, 696 (2015).

20. Reuter, M. Viruslike particles in Gyratrix hermaphroditus (Turbellaria: Rhabdocoela). J. Invertebr. Pathol. 25, 79-95 (1975). 
21. Vijayan, K. K. et al. Polychaete worms-a vector for white spot syndrome virus (WSSV). Dis. Aquat. Org. 63, 107-111 (2005).

22. Nobiron, I. et al. Genome and polypeptides characterization of Tellina virus 1 reveals a fifth genetic cluster in the Birnaviridae family. Virology 371, 350-361 (2008).

23. Crespo-González, C. et al. Virus-like particles in Urastoma cyprinae, a turbellarian parasite of Mytilus galloprovincialis. Dis. Aquat. Organ. 79, 83-86 (2008).

24. Marhaver, K. L., Edwards, R. A. \& Rohwer, F. Viral communities associated with healthy and bleaching corals. Environ. Microbiol. 10, 2277-2286 (2008).

25. Claverie, J.-M. et al. Mimivirus and Mimiviridae: giant viruses with an increasing number of potential hosts, including corals and sponges. J. Invertebr. Pathol. 101, 172-180 (2009).

26. Jackson, E. W., Bistolas, K. S. I., Button, J. B. \& Hewson, I. Novel circular single-stranded DNA viruses among an asteroid, echinoid and holothurian (Phylum: Echinodermata). PLoS ONE 11, e0166093 (2016).

27. Suttle, C. A. Viruses in the sea. Nature 437, 356-361 (2005).

28. Brum, J. R., Schenck, R. O. \& Sullivan, M. B. Global morphological analysis of marine viruses shows minimal regional variation and dominance of non-tailed viruses. The ISME J 7, 1738-1751 (2013).

29. Middelboe, M. \& Brussaard, C. Marine viruses: key players in marine ecosystems. Viruses 9, E302 (2017).

30. Vacelet, J. \& Gallissian, M.-F. Virus-like particles in the cells of the sponge Verongia cavernicola (Demospongiae, Dictyoceratida) and accompanying tissues changes. J. Invertebr. Pathol. 31, 246-254 (1978).

31. Luter, H. M., Whalan, S. \& Webster, N. S. Exploring the role of microorganisms in the disease-like syndrome affecting the sponge Lanthella basta. Appl. Environ. Microbiol. 76, 5736-5744 (2010).

32. Pascelli, C., Laffy, P. W., Kupresanin, M., Ravasi, T. \& Webster, N. S. Morphological characterization of virus-like particles in coral reef sponges. PeerJ 6, e5625 (2018).

33. Lohr, J. E., Chen, F. \& Hill, R. T. Genomic analysis of bacteriophage JL001: insights into its interaction with a sponge-associated alpha-Proteobacterium. Appl. Environ. Microbiol. 71, 1598-1609 (2005).

34. Lohr, J., Munn, C. B. \& Wilson, W. H. Characterization of a latent virus-like infection of symbiotic zooxanthellae. Appl. Environ. Microbiol. 73, 2976-2981 (2007).

35. Patten, N. L., Harrison, P. L. \& Mitchell, J. G. Prevalence of virus-like particles within a staghorn scleractinian coral (Acropora muricata) from the Great Barrier Reef. Coral Reefs 27, 569-580 (2008).

36. van Oppen, M. H., Leong, J.-A. \& Gates, R. D. Coral-virus interactions: A double-edged sword?. Symbiosis 47, 1-8 (2009).

37. Vega Thurber, R. L. \& Correa, A. M. S. Viruses of reef-building scleractinian corals. J. Exp. Mar. Biol. Ecol. 408, 102-113 (2011).

38. Leruste, A., Bouvier, T. \& Bettarel, Y. Enumerating viruses in coral mucus. Appl. Environ. Microbiol. 78, 6377-6379 (2012).

39. Pollock, F. J. et al. Abundance and morphology of virus-like particles associated with the coral Acropora hyacinthus differ between healthy and white syndrome-infected states. Mar. Ecol. Prog. Ser. 510, 39-43 (2014).

40. Correa, A. M. S. et al. Viral outbreak in corals associated with an in situ bleaching event: atypical herpes-like viruses and a new megavirus infecting Symbiodinium. Front. Microbiol. 7, 127 (2016).

41. Farley, C. A. Viruses and viruslike lesions in marine mollusks. Mar. Fish. Rev. 40, 18-20 (1978).

42. Elston, R. A. Bivalve mollusc viruses. World J. Microbiol. Biotechnol. 13, 393-403 (1997).

43. Renault, T. \& Novoa, B. Viruses infecting bivalve molluscs. Aquat. Living Resour. 17, 397-409 (2004).

44. Richards, G. P. et al. Bacteriophages against pathogenic vibrios in Delaware Bay oysters (Crassostrea virginica) during a period of high levels of pathogenic Vibrio parahaemolyticus. Food Environ. Virol. 11, 101-112 (2019).

45. Leigh, B., Karrer, C., Cannon, J. P., Breitbart, M. \& Dishaw, L. J. Isolation and characterization of a Shewanella phage-host system from the gut of the tunicate Ciona intestinalis. Viruses 9, E60 (2017).

46. Winston, J. E. Feeding in marine bryozoans. In Biology of Bryozoans (eds Woollacott, R. M. \& Zimmer, R. L.) 233-271 (Academic Press, London, 1977).

47. Winston, J. E. Polypide morphology and feeding behaviour in marine ectoprocts. Bull. Mar. Sci. 28, 1-31 (1978).

48. Shunatova, N. N. \& Ostrovsky, A. N. Individual autozooidal behaviour and feeding in marine bryozoans. Sarsia 86, 113-142 (2001).

49. Shunatova, N. \& Ostrovsky, A. Group autozooidal behaviour and chimneys in marine bryozoans. Mar. Biol. 140, 503-518 (2002).

50. Schwaha, T. F., Ostrovsky, A. N. \& Wanninger, A. Key novelties in the evolution of Bryozoa: evidence from the soft-body morphology. Biol. Rev. 95, 696-729 (2020).

51. Ryland, J. S. Bryozoans (Hutchinson University Library, London, 1970).

52. Ryland, J. S. Bryozoa: an introductory overview. In Moostiere (Bryozoa). Denisia Vol. 16 (ed. Woess, E.) 9-22 (Springer, Linz, 2005).

53. McKinney, F. K. \& Jackson, J. D. C. Bryozoan Evolution (Unwin Hyman, Boston, MA, 1989).

54. Nielsen, C. Bryozoa (Ectoprocta: 'Moss' animals). eLS 1, 1-6. https://doi.org/10.1002/9780470015902.a0001613.pub2 (2013).

55. Lutaud, G. Sur la présence de microorganismes spécifiques dans les glandes vestibulaires et dans l'aviculaire de Palmicellaria skenei (Ellis et Solander) Bryozoaire Chilostome. Cah. Biol. Mar. 6, 181-190 (1965).

56. Lutaud, G. La nature des corps funiculaires des cellularines Bryozoaires Chilostomes. Arch. Zool. Exp. Gen. 110, 2-30 (1969).

57. Lutaud, G. L'infestation du myoépithélium de loesophage par des microorganismes pigmentés et la structure des organes à bactéries du vestibule chez le Bryozoaire Chilostome Palmicellaria skenei (E. et S.) Can. J. Zool. 64, 1842-1851 (1986).

58. Woollacott, R. M. \& Zimmer, R. L. A simplified placenta-like system for the transport of extraembryonic nutrients during embryogenesis of Bugula neritina (Bryozoa). J. Morphol. 147, 355-377 (1975).

59. Dyrynda, P. E. J. \& King, P. E. Sexual reproduction in Epistomia bursaria (Bryozoa: Cheilostomata), an endozooidal brooder without polypide recycling. J. Zool. 198, 337-352 (1982).

60. Moosbrugger, M., Schwaha, T., Walzl, M. G., Obst, M. \& Ostrovsky, A. N. The placental analogue and the pattern of sexual reproduction in the cheilostome bryozoan Bicellariella ciliata (Gymnolaemata). Front. Zool. 9, 29 (2012).

61. Mathew, M., Schwaha, T., Ostrovsky, A. N. \& Lopanik, N. B. Symbiont-dependent sexual reproduction in marine colonial invertebrate: Morphological and molecular evidence. Mar. Biol. 165, 14 (2018).

62. Karagodina, N. P., Vishnyakov, A. E., Kotenko, O. N., Maltseva, A. L. \& Ostrovsky, A. N. Ultrastructural evidence for nutritional relationships between a marine colonial invertebrate (Bryozoa) and its bacterial symbionts. Symbiosis 75, 155-164 (2018).

63. Woollacott, R. M. Association of bacteria with bryozoan larvae. Mar. Biol. 65, 155-158 (1981).

64. Zimmer, R. L. \& Woollacott, R. M. Mycoplasma-like organisms: occurrence with the larvae and adults of a marine bryozoan. Science 220, 208-210 (1983).

65. Zimmer, R. L. \& Woollacott, R. M. Larval morphology of the bryozoan Watersipora arcuata (Cheilostomata: Ascophora). J. Morphol. 199, 125-150 (1989).

66. Boyle, P. J., Maki, J. S. \& Mitchell, R. Mollicute identified in novel association with aquatic invertebrate. Curr. Microbiol. 15, 85-89 (1987).

67. Lim, G. E. \& Haygood, M. G. “Candidatus Endobugula glebosa”, a specific bacterial symbiont of the marine bryozoan Bugula simplex. Appl. Environ. Microbiol. 70, 4921-4929 (2004).

68. Sharp, K. H., Davidson, S. K. \& Haygood, M. G. Localization of 'Candidatus Endobugula sertula' and the bryostatins throughout the life cycle of the bryozoan Bugula neritina. ISME J. 1, 693-702 (2007).

69. Lim-Fong, G. E., Regali, L. A. \& Haygood, M. G. Evolutionary relationships of “Candidatus Endobugula” bacterial symbionts and their Bugula bryozoan hosts. Appl. Environ. Microbiol. 74, 3605-3609 (2008). 
70. Richardson, K. C., Jarrett, L. \& Finke, E. H. Embedding in epoxy resins for ultrathin sectioning in electron microscopy. Stain. Technol. 35, 313-323 (1960).

71. Mäntynen, S., Sundberg, L.-R., Oksanen, H. M. \& Poranen, M. M. Half a century of research on membrane-containing bacteriophages: bringing new concepts to modern virology. Viruses 11, E76 (2019).

72. Cuozzo, S. A., Castellano, P., Sesma, F. J., Vignolo, G. M. \& Raya, R. R. Differential roles of the two-component peptides of lactocin 705 in antimicrobial activity. Curr. Microbiol. 46, 180-183 (2003).

73. Chibani-Chennoufi, S., Bruttin, A., Dillmann, M. L. \& Brüssow, H. Phage-host interaction: An ecological perspective. J. Bacteriol. 186, 3677-3686 (2004)

74. Haygood, M. G. \& Davidson, S. K. Small-subunit rRNA genes and in situ hybridization with oligonucleotides specific for the bacterial symbionts in the larvae of the bryozoan Bugula neritina and proposal of "Candidatus Endobugula sertula". Appl. Environ. Microbiol. 63, 4612-4616 (1997).

75. Ostrovsky, A. N., Gordon, D. P. \& Lidgard, S. Independent evolution of matrotrophy in the major classes of Bryozoa: Transitions among reproductive patterns and their ecological background. Mar. Ecol. Prog. Ser. 378, 113-124 (2009).

76. Ostrovsky, A. N. Evolution of Sexual Reproduction in Marine Invertebrates: Example of Gymnolaemate Bryozoans (Springer, Dordrecht, Heidelberg, NewYork, London, 2013).

77. Ostrovsky, A. N. From incipient to substantial: evolution of placentotrophy in a phylum of aquatic colonial invertebrates. Evolution 67, 1368-1382 (2013).

78. Miller, I. J., Vanee, N., Fong, S. S., Lim-Fong, G. E. \& Kwan, J. C. Lack of overt genome reduction in the bryostatin-producing bryozoan symbiont "Candidatus Endobugula sertula". Appl. Environ. Microbiol. 82, 6573-6583 (2016).

79. Miller, I. J., Weyna, T. R., Fong, S. S., Lim-Fong, G. E. \& Kwan, J. C. Single sample resolution of rare microbial dark matter in a marine invertebrate metagenome. Sci. Rep. 6, 34362 (2016).

80. Ostrovsky, A. N. \& Porter, J. S. Pattern of occurrence of supraneural coelomopores and intertentacular organs in Gymnolaemata (Bryozoa) and its evolutionary implications. Zoomorphology 130, 1-15 (2011).

81. Shikuma, N. J., Pilhofer, M., Weiss, G. L., Hadfield, M. G. \& Jensen, G. J. Marine tubeworm metamorphosis induced by arrays of bacterial phage tail-like structures. Science 343, 529-533 (2014).

82. Leiman, P. G. et al. Type VI secretion apparatus and phage tail-associated protein complexes share a common evolutionary origin. Proc. Nat. Acad. Sci. 106, 4154-4159 (2009).

83. Taylor, N. M. I., van Raaij, M. J. \& Leiman, P. G. Contractile injection systems of bacteriophages and related systems. Mol. Microbiol. 108, 6-15 (2018)

84. Lawrence, S. A., Wilson, W. H., Davy, J. E. \& Davy, S. K. Latent virus-like infections are present in a diverse range of Symbiodinium spp. (Dinophyta). J. Phycol. 50, 984-997 (2014).

85. Ericson, C. F. et al. A contractile injection system stimulates tubeworm metamorphosis by translocating a proteinaceous effector. eLife 8, e46845 (2019).

86. Ackermann, H. W. Basic phage electron microscopy. Methods Mol. Biol. 501, 113-126 (2009).

87. Moran, N. A., Degnan, P. H., Santos, S. R., Dunbar, H. E. \& Ochman, H. The players in a mutualistic symbiosis: insects, bacteria, viruses, and virulence genes. Proc. Natl. Acad. Sci. USA 102, 16919-16926 (2005).

88. Weldon, S. R. \& Oliver, K. M. Diverse bacteriophage roles in an aphid-bacterial defensive mutualism. In Advances in Environmental Microbiology Vol. 2 (ed. Hurst, C. J.) 173-206 (Springer, Berlin, 2016).

89. Rohwer, F. \& Thurber, R. V. Viruses manipulate the marine environment. Nature 459, 207-212 (2009).

90. Roossinck, M. J. The good viruses: viral mutualistic symbioses. Nat. Rev. Microbiol. 9, 99-108 (2011).

91. Sharp, J. H., Winson, M. K. \& Porter, J. S. Bryozoan metabolites: an ecological perspective. Nat. Prod. Rep. 24, 659-673 (2007).

92. Maltseva, A. L. et al. Novel brominated metabolites from Bryozoa: a functional analysis. Nat. Prod. Res. 31, 1840-1848 (2016).

\section{Acknowledgements}

This study was performed using the laboratories and equipment of the Centre for Molecular and Cell Technologies, Saint Petersburg State University. Dr K. Tilbrook, Oxford University, kindly helped during collecting and identification of the Australian material. Drs A. Hoggett and L. Vail, Lizard Island Research Station, Australian Museum, kindly provided all the necessary help during field work on the Great Barrier Reef. We thank Dr M. Stachowitsch, University of Vienna, for linguistically revising the early draft of the manuscript. Planning of the research, TEM microscopy, data processing and analysis, and manuscript preparation were performed at the Saint Petersburg State University, being funded by the Russian Science Foundation (grant 18-14-00086). The animal samples for microscopy were processed at the facilities of the University of Vienna. The E. coli samples processing and a part of the data analysis were performed at Winogradsky Institute of Microbiology, Research Centre "Biotechnology" of the Russian Academy of Sciences under the State assignment from the Ministry of education and Science of Russian federation..

\section{Author contributions}

A.V., A.L. and A.O. designed the study, analysed the data and wrote the manuscript. A.L. and P.I. performed the experiments. A.O. and G.L. collected material. G.L. contributed to data interpretation and writing the manuscript. T.S. processed fixed material and contributed to data interpretation. A.V. and N.K. performed microscopical study. All authors have read and approved the manuscript.

\section{Competing interests}

The authors declare no competing interests.

\section{Additional information}

Correspondence and requests for materials should be addressed to A.V.L. or A.N.O.

Reprints and permissions information is available at www.nature.com/reprints.

Publisher's note Springer Nature remains neutral with regard to jurisdictional claims in published maps and institutional affiliations. 
(c) (i) Open Access This article is licensed under a Creative Commons Attribution 4.0 International cc) License, which permits use, sharing, adaptation, distribution and reproduction in any medium or format, as long as you give appropriate credit to the original author(s) and the source, provide a link to the Creative Commons licence, and indicate if changes were made. The images or other third party material in this article are included in the article's Creative Commons licence, unless indicated otherwise in a credit line to the material. If material is not included in the article's Creative Commons licence and your intended use is not permitted by statutory regulation or exceeds the permitted use, you will need to obtain permission directly from the copyright holder. To view a copy of this licence, visit http://creativecommons.org/licenses/by/4.0/.

(C) The Author(s) 2021 